\title{
PRELIMINARY RECONNAISSANCE REPORT FOR THE KASHMIR EARTHQUAKE OF 8 OCTOBER 2005
}

\author{
G.D. Dellow ${ }^{1}$, Q. Ali \& S.M. Ali ${ }^{2}$, S. Hussain ${ }^{3}$, \\ B. Khazai ${ }^{4}$ \& A. Nisar ${ }^{5}$
}

This paper was presented at the NZSEE Annual Conference at Napier, New Zealand, 10-12 March 2006.

\begin{abstract}
:
A magnitude (Mw) 7.6 earthquake occurred at 8.55 am (local time) on 8 October 2005 causing extensive damage to buildings, bridges and roads and killing in excess of 87,000 people in the Kashmir region of northern Pakistan. Damage and deaths were also reported from Indian Administered Kashmir and eastern Afghanistan. The most severely affected region was in the epicentral area around Muzaffarabad in Pakistan Administered Kashmir. Reverse or thrust fault rupture on or near the Main Boundary Thrust of the Himalayas has been reported or observed from Chennari in the Jhelum River valley upstream of Muzaffarabad through to Muzaffarabad and over into the Kaghan valley as far north as Balakot, a distance of approximately $60 \mathrm{~km}$. A notable feature of the effects of this earthquake was the asymmetric distribution of landslides across the fault rupture zone. On the downthrown or footwall side (to the southwest) landslide damage was relatively minor - the road from Manshera to Muzaffarabad was open to traffic within 8 hours of the earthquake and required the clearance of only one landslide. On the upthrown or hanging wall side of the fault rupture zone (to the northeast) the road from Balakot to Kagan required the clearance of 253 landslides and took 24 days. These observations are consistent with the findings of recent strong motion studies.
\end{abstract}

\section{INTRODUCTION}

A magnitude $\left(\mathrm{M}_{\mathrm{w}}\right) 7.6$ earthquake at 8.50 am (local time) on 8 October 2005 (USGS, 2005) caused extensive damage and killed in excess of 87,000 people in the Kashmir region of northern Pakistan. Damage and deaths where reported from India in Indian Administered Kashmir, from Pakistan in Pakistan Administered Kashmir and the North West Frontier Province and from eastern Afghanistan. The most severely affected region was in the epicentral area around Muzaffarabad in Pakistan Administered Kashmir and in particular in a band $\sim 10 \mathrm{~km}$ wide and $\sim 60 \mathrm{~km}$ long to the northeast of the fault zone which ruptured during the earthquake, forming a surface trace $\sim 60 \mathrm{~km}$ long. To the northeast of the fault zone are the foothills of the Indus Kohistan. To the southwest of the fault trace (Figure 1) are the Pir Panchal Ranges in the south and the valleys of the Jhelum and Kaghan Rivers adjacent to the Mansehra/Abbottabad Plateau in the west.

\begin{abstract}
An invitation to join a reconnaissance team to visit the region devastated by the Kashmir earthquake of 8 October 2005 was extended to the New Zealand Society for Earthquake Engineering (NZSEE) by the US based Earthquake Engineering Research Institute (EERI). Because initial reports indicated that landslides had caused major problems for response and recovery activities an engineering geologist familiar with earthquake-induced landslides was selected by NZSEE to join the EERI team. In Pakistan, the team was hosted by the Civil Engineering Department of the University of Engineering and Technology, Peshawar. The team assembled in Islamabad, Pakistan on the 13 November 2005 and comprised the authors of this paper. From the 14-17 November the team spent four days examining earthquake damage and response and recovery activities primarily in Abbottabad and Muzaffarabad and undertook an aerial reconnaissance of the epicentral area courtesy of the Pakistani Army. On the 18-19 November the team participated in a conference in Islamabad (Earthquake Rehabilitation Conference - Theme 1: Seismology, Structures and Codes).
\end{abstract}

${ }^{1}$ GNS Science, Lower Hutt. (Member)

${ }^{2}$ Department of Civil Engineering, University of Engineering and Technology, Peshawar, Pakistan

${ }^{3}$ Coffman Engineers Inc., Encino, California, United States

${ }^{4}$ Centre for Hazards and Risk Research, Earth Institute at Columbia University, United States

${ }^{5}$ MMI Engineering, San Francisco, California, United States 
This paper outlines the tectonic, geological and physiographic settings in the epicentral area of the earthquake. Ground damage caused by the earthquake and observed by the reconnaissance team, including the ground surface trace of the fault rupture and landslide damage and its distribution in relation to the fault rupture zone are described. Building damage is discussed and variations from expected shaking damage to buildings are noted.

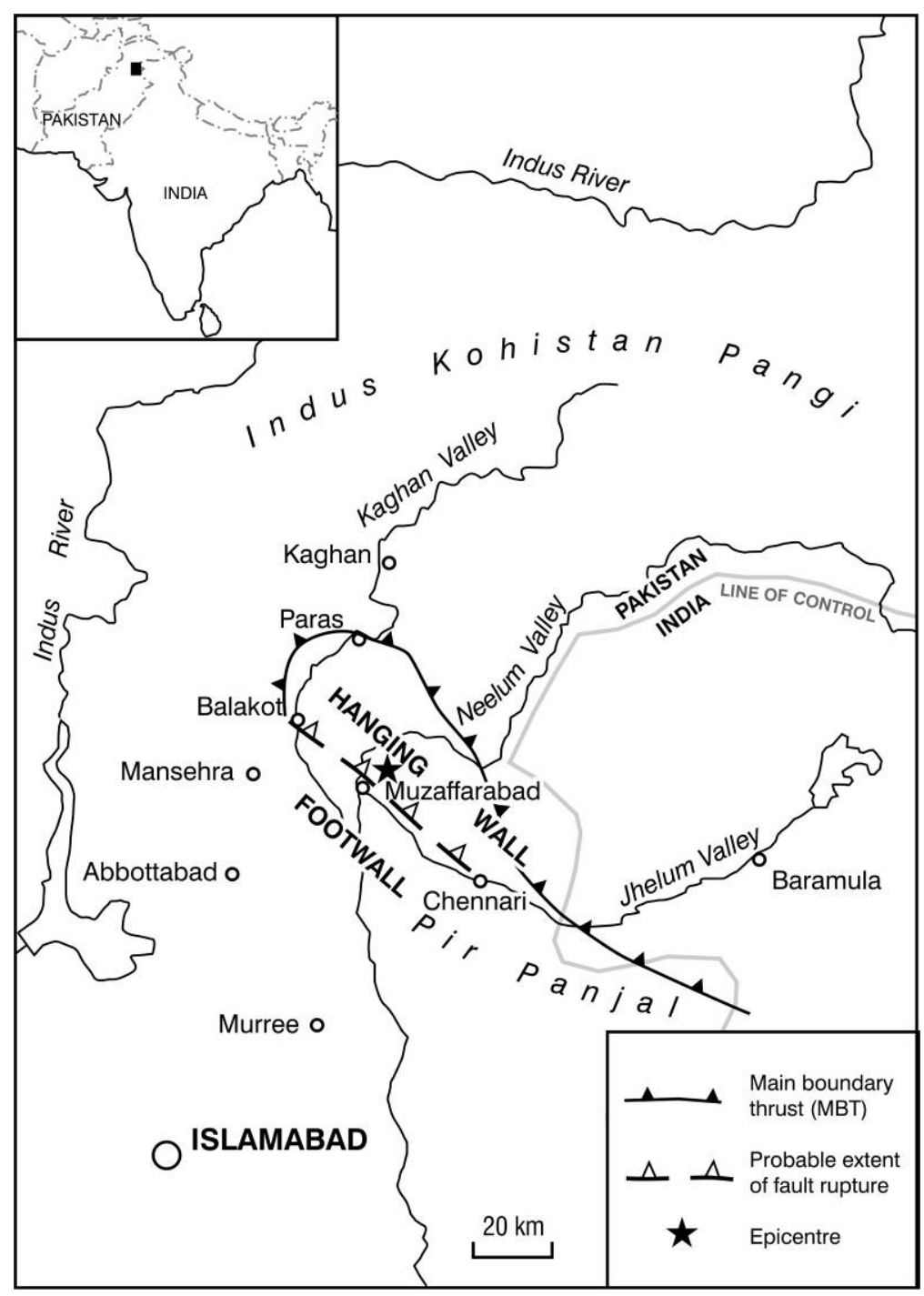

Figure 1. Location diagram for the area around the fault rupture associated with the Kashmir earthquake of 8 October 2005.

\section{SETTING}

The magnitude 7.6 earthquake of 8 October 2005 was associated with fault rupture near the western end of the Main Boundary Thrust (MBT) in Pakistan Administered Kashmir and the North West Frontier Province, north-eastern Pakistan (Figure 1). The MBT is the main tectonic structure on the southern front of the Himalayas and extends in a southward curved arc, a distance of 2,500 km from Pakistan, through northwest India, to Nepal and northeast India (Bird, 2003). The MBT is the active tectonic boundary between the colliding continental crusts of the Eurasian plate on the northern side of the MBT which is being thrust over the Indo-Australian plate on the southern side. At the western end of the MBT in north-eastern Pakistan the fault has an approximate northwest-southeast strike.
The physiography of the area around the earthquake epicentral region varies. On the north-eastern side of the fault are the foothills of the Indus Kohistan (Nanga Prabat $8,126 \mathrm{~m}$ ). The main river valleys in this area are the Neelum (forks off the Jhelum at Muzaffarabad) and the Kaghan (forks off the Jhelum downstream of Muzaffarabad but crosses the MBT near Balakot), (Figure 1). The floors of these valleys are at an elevation of $\sim 800 \mathrm{~m}$ with the ridge crests rising $\sim 500-1,500 \mathrm{~m}$ above this near Muzaffarabad. On the south-western side of the MBT are the Pir Panchal Ranges in the south and the Mansehra-Abbottabad Plateau in the west. The plateau is at an elevation of $\sim 1,200 \mathrm{~m}$ and on its north-eastern margin is the Kaghan Valley (between its forks with the Jhelum River and the town of Balakot).

The geology of the area consists of several indurated sedimentary and metamorphic rock types forming the 
basement rock mass, which in the valleys is overlain by more recent (Quaternary age) coarse fluvio-glacial gravels. At Muzaffarabad a shattered dolomite unit was observed on the up-thrown side of the fault and could be traced for several kilometres from the distinctive white landslide scars (Cambrian Abbottabad Formation). In the Jhelum River valley upstream of Muzaffarabad a sequence of metrebedded siltstones and sandstones dipping in a general southwest direction forms the valley wall (scarp slope) of the Jhelum River valley on the down-thrown or south-western side of the fault (Late Paleocene to Eocene Murree Formation). In the Kaghan valley between Muzaffarabad and Balakot, pelitic schist forms the local basement (PreCambrian Hazara Formation).

The younger overlying sediments in the major river valleys are alluvial deposits and consist mainly of coarse gravels (up to boulder size) with very few fines (sand, silt and clay). The alluvial gravels form narrow terraces which are over $100 \mathrm{~m}$ above the current river level in places. On the higher (older) terraces these gravels are weakly to moderately cemented, but are generally unweathered. Where smaller side valleys enter the main valleys steep alluvial fans are formed by similar alluvial gravels, often with deeply incised stream channels.

The only area where the geology is significantly different to that of the epicentral area is the Mansehra-Abbottabad Plateau to the west (Figure 1). The higher areas of the plateau (Mansehra and further north) are underlain by a sequence of fine-medium grained alluvial gravels. However, near Abbottabad there is a unit of cohesive soils (clays) underlying a former marshland and the water table in this unit is within 1-2 $\mathrm{m}$ of the ground surface.

\section{FAULT RUPTURE}

Fault rupture at the ground surface was observed in a number of places including Muzafferabad (by the EERI/NZSEE Reconnaissance Team); Balakot (Pakistan Geological Survey) and at Chennari (local source). The length of the reported fault rupture is $\sim 60 \mathrm{~km}$ and extends from Chennari in the southeast (located upstream of Muzaffabad in the Jhelum River valley), to pass 2-3 $\mathrm{km}$ to the east of Muzaffarabad before terminating near Balakot in the Kaghan valley to the northwest (Figure 1).

First-hand observations of fault rupture were made by the reconnaissance team in the Neelum River valley 2-3 km north of Muzaffarabad. At this site ground rupture striking sub-parallel to the trend of the river valley crossed a high terrace surface ( $\sim 20 \mathrm{~m}$ above river level). The terrace surface between the river and the rupture had been uplifted $\sim 1 \mathrm{~m}$ relative to the terrace surface between the rupture and the adjacent hill slopes. The ground rupture could be traced for $\sim 50$ metres. At a number of places where linear features (fence lines and concrete pads) traversed the rupture no evidence for lateral offset could be seen (i.e. the movement on the fault plane was entirely dip slip with no detectable strike-slip component). At an exposure on a steep terrace riser where the ground rupture intersected the terrace edge at an oblique angle, the stratigraphic contact between shattered dolomite and the overlying recent coarse alluvial gravels was offset in the plane of the ground rupture. On the terrace surface the offset from the most recent event was $\sim 1 \mathrm{~m}$ (Figure 2). However, the dolomite/gravel contact was offset in the order of $2.5 \mathrm{~m}$ indicating that this fault has probably ruptured on at least two occasions since the terrace surface was formed. Also, the fact that the dolomite rock unit is present on both sides of the fault rupture indicates that this is probably not the primary fault plane, but a secondary rupture in an area where the fault zone is more complex.

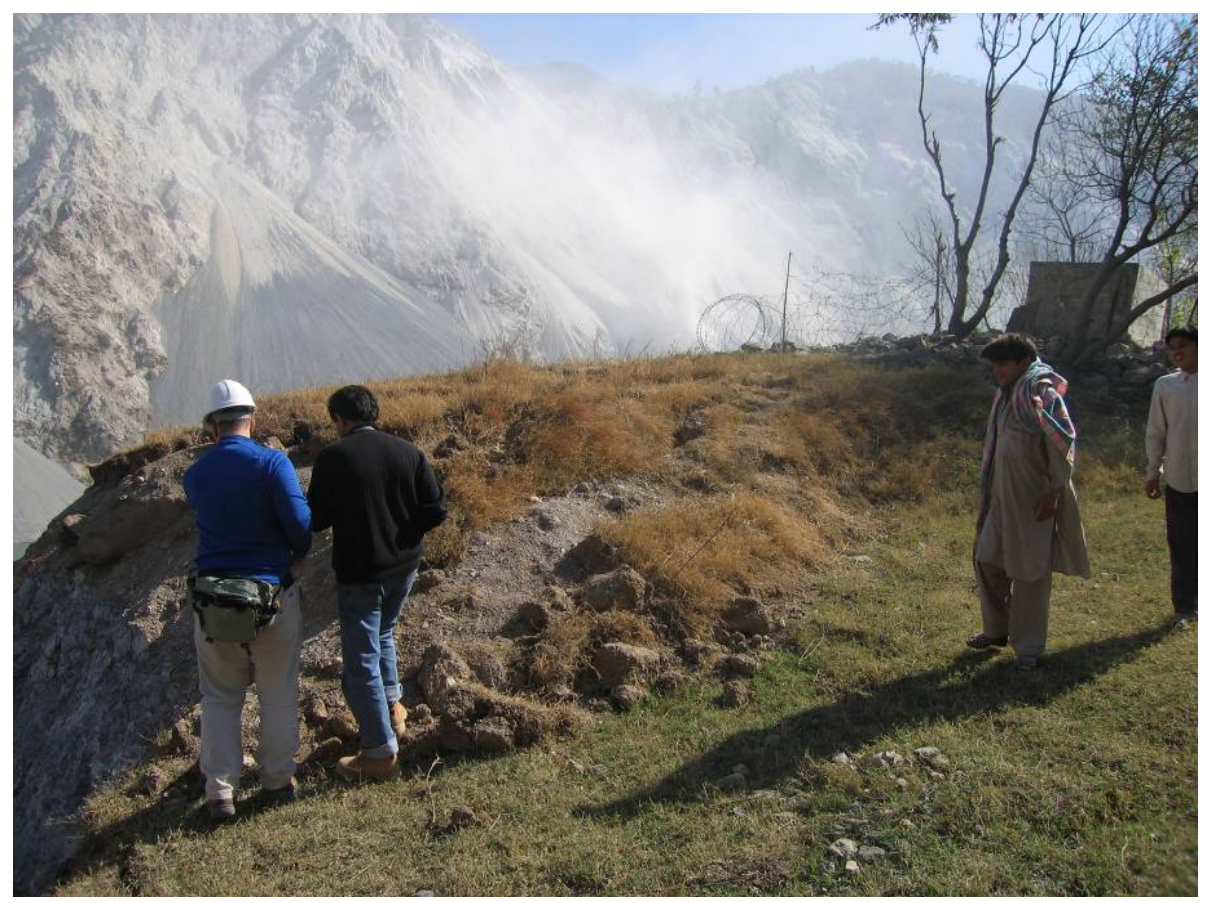

Figure 2. The surface trace of the fault plane that ruptured during the 8 October earthquake can be seen as the vertical offset of the formerly continuous sub-horizontal terrace surface that the people are standing on. The fault trace has a vertical offset of $\sim 1 \mathrm{~m}$ at this site. On the other side of the Neelum River valley can be seen some of the distinctive white landslide scars formed by disrupted rock slides developed in a dolomite unit. 
The seismological and observed ground surface fault rupture data are consistent with the tectonic setting. The relative offset observed along the fault was up to the northeast and down to the southeast with no lateral offset. The provisional epicentre was located $\sim 10 \mathrm{~km}$ to the northeast of the fault rupture. This data is consistent with the earthquake occurring on a reverse or thrust fault. Observance of fault rupture was surprising given that the earthquake was initially thought to have occurred on the MBT.

\section{LANDSLIDES}

The size and frequency distribution of landslides produced by this earthquake is highly asymmetric with three distinct areas able to be delineated. The first group of landslides have formed adjacent to or over the trace of the fault rupture at the ground surface with a near continuous line of landslides visible from Muzaffarabad through to Balakot (Figure 3). On the northeast (up-thrown or hanging wall) side of the fault trace landslides are common and extend $\sim 10-20 \mathrm{~km}$ from the fault trace, whereas on the southwest (downthrown or footwall) side of the fault landslides are generally rare except within $2-3 \mathrm{~km}$ of the fault trace.
The landslides formed along the fault trace can be separated into three distinct groups. At the south-eastern end, between Chennari and Muzaffarabad along the valley of the Jhelum River landslides $\left(100-10,000 \mathrm{~m}^{3}\right)$ are common but do not clearly delineate the fault trace. Along the central part of the fault trace from Muzzaffarabad and over the range separating the Jhelum and Kaghan river valleys, disrupted rock slides $\left(1,000-1,000,000 \mathrm{~m}^{3}\right)$ with source areas in a shattered dolomite on the leading edge of the hanging wall coalesce to form a near continuous feature delineating the fault trace (Figure 3). Approximately 2-3 km north of Muzaffarabad this lineation becomes poorly defined for several kilometres and may indicate an area of more complex surface faulting possibly due to a change in strike of the fault. However, a single clearly defined line of landslides is also evident to the northwest of this in the Kaghan valley. At the north-western end of the fault trace a third group of landslides $(10,000$ $1,000,000 \mathrm{~m}^{3}$ ) was observed following the line of the fault rupture. These landslides are mainly soil block slides (slumps), with rotational slide planes inferred from the apparent back-tilting of surfaces in the head-scarp area. Along the central and north-western portions of the fault trace the width of the zone affected by landslides varies from tens of metres up to a few hundred metres and has probably modified or destroyed the fault trace in many places.

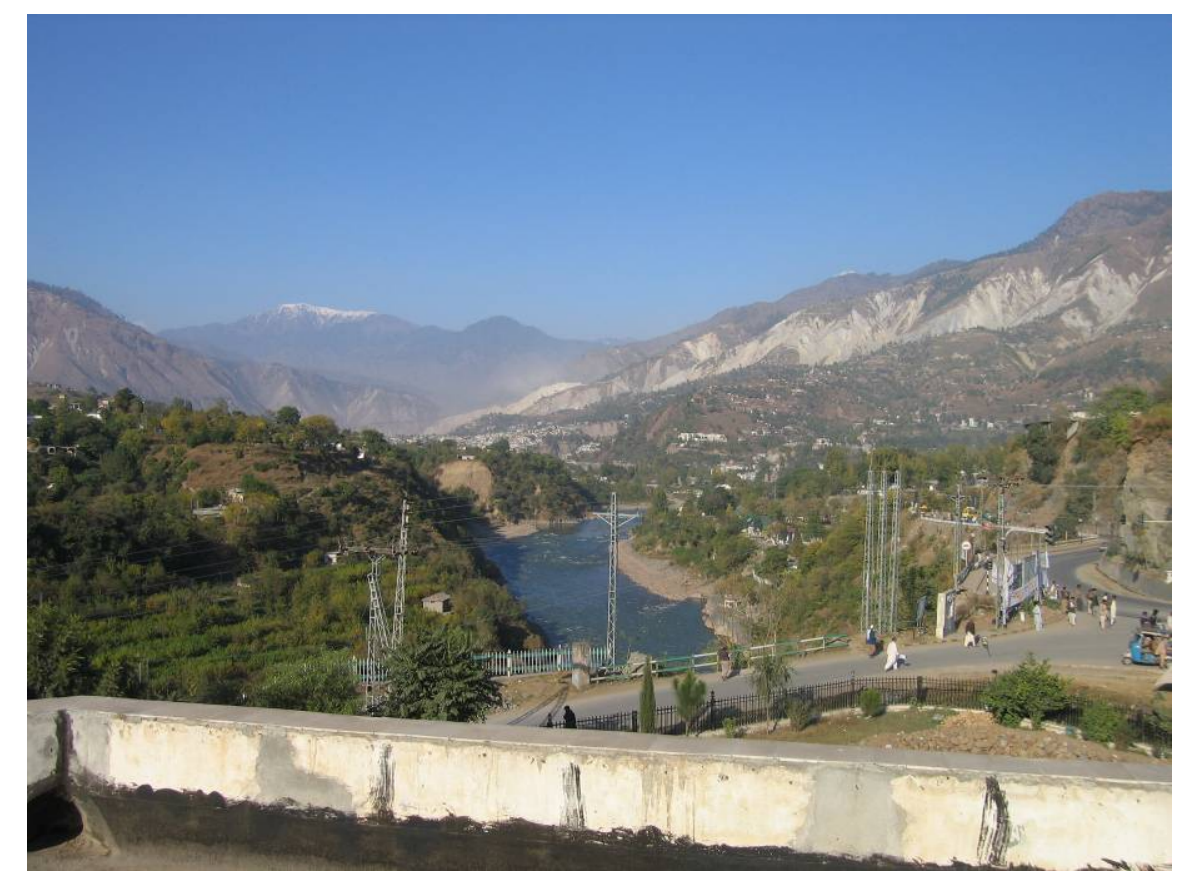

Figure 3. The distinctive white scars formed by landslides (disrupted rock and debris slides) developed in a dolomite on the hanging wall side of the fault trace have coalesced and delineate the approximate location of the fault rupture.

On the north-eastern (up-thrown or hanging wall) side of the fault landslides are common $\left(100-100,000 \mathrm{~m}^{3}\right)$. For example, the road from Muzaffarabad into the Neelum River valley and the road from Balakot to Kaghan (upstream of Balakot in the Kaghan valley) were blocked by numerous landslides for several weeks after the earthquake. These landslides greatly hindered ground-based relief operations in the area as they destroyed the primary access routes into these valleys and their tributaries, effectively isolating a large area.

On the southwest side of the fault zone very few landslides were observed. These landslides were in two distinct areas, landslides within 2-3 km of the fault zone, and landslides further away. Landslides within $2-3 \mathrm{~km}$ of the fault zone were observed in Muzaffarabad and in the Jhelum River valley upstream of Muzaffarabad and were either soil falls (100-1,000 $\mathrm{m}^{3}$ ) involving alluvial gravels from steep river terrace and fan terrace risers or rock falls $\left(100-1,000 \mathrm{~m}^{3}\right)$ from sub-vertical road cuts up to $20 \mathrm{~m}$ high formed in the scarp slope of an inter-bedded sequence of indurated sandstones and mudstones. Several larger shallow (1-2 m) translational soil slides $\left(1,000-10,000 \mathrm{~m}^{3}\right)$ on the northeast side of the Jhelum River upstream of Muzaffarabad may also belong to this group but as the exact location of the fault zone 
in this area is currently uncertain they cannot be assigned to a particular set with confidence. Further away from the fault zone landslides were rare with the Mansehra-Muzzaffarabad road only being blocked at one site in the Kaghan valley with a previous history of instability problems. A few small rock and soil falls $\left(<10 \mathrm{~m}^{3}\right)$ from $4-5 \mathrm{~m}$ high road cuts were noted but these did not block the road (on the descent into the Kaghan valley when travelling from Mansehra).

One discrepancy in this asymmetric distribution of landslides was a very large rock avalanche that occurred in the Pir Panchal Ranges on the downthrown or footwall side of the fault. This landslide is $\sim 2 \mathrm{~km}$ long from its head-scarp on a ridge crest to its toe, where several tens of millions of cubic metres of debris have formed a large landslide dam in the fork of a river valley, and is currently (17 November 2005) impounding lakes in both valleys (Figure 4). This is the largest single landslide caused by the earthquake. There is a risk the landslide dam will fail catastrophically during overtopping (or possibly earlier) releasing the lake waters impounded behind the dam in a dam-break flood event endangering the lives of those living in the valley floors downstream.

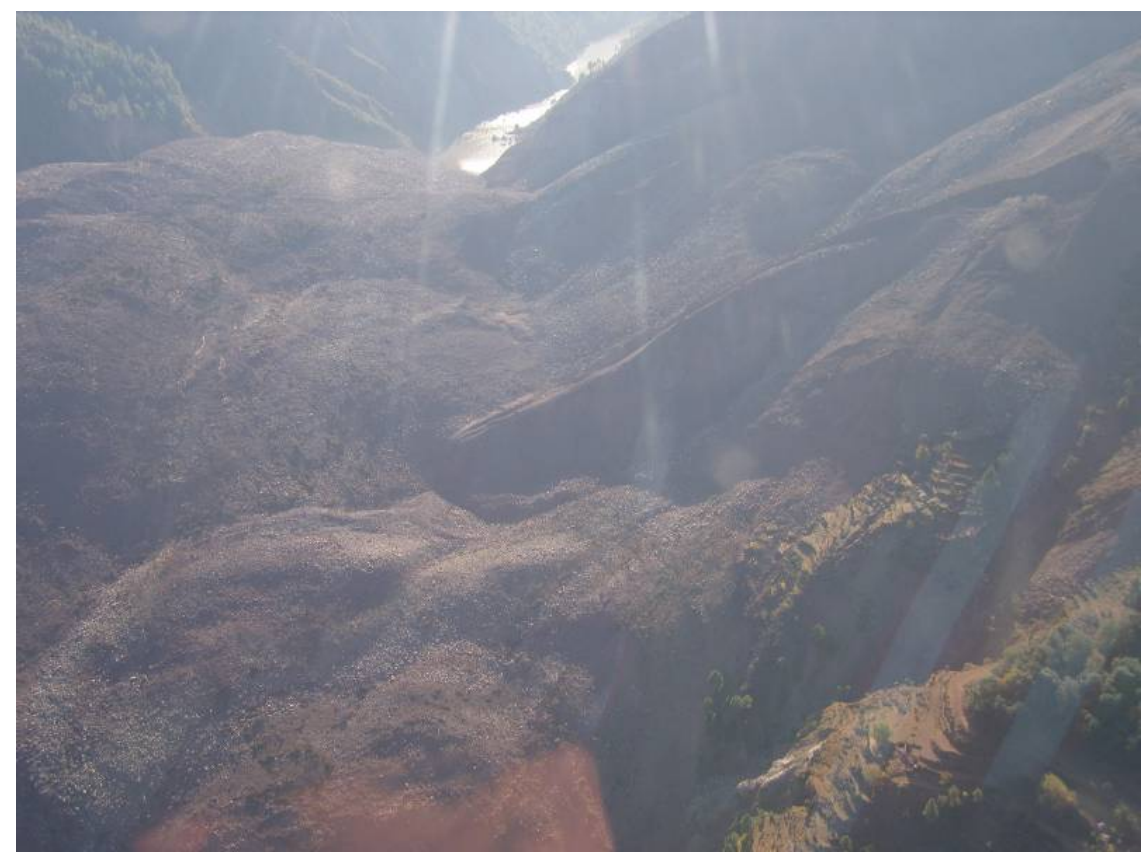

Figure 4. Several tens of millions of cubic metres of rock avalanche debris have blocked two valleys in the Pir Panchal Ranges and water is now impounding behind the landslide dam. This rock avalanche is the largest known landslide caused by the 8 October earthquake and has a track over 2 km long.

The marked asymmetry in the landslide distribution on either side of the fault trace can perhaps be best illustrated by the length of time it took to re-establish road links of similar length on either side of the fault. On the footwall side, the roads from Abbottabad to Mansehra and then onto either Balakot or Muzaffarabad were open to vehicular traffic within 8 hours of the earthquake occurring (this is consistent with the observed landslide damage). On the hanging wall side of the fault the road from Balakot to Kaghan up the Kaghan valley required the clearance of some 253 landslides which took 24 days (www.pakistanlink.com/

Headlines/Nov05/06/02.htm), while the road up the Neelum River valley from Muzaffarabad took more than a week to clear. The difference in the distribution of landslides on either side of the fault rupture zone, with landslides having a greater frequency and magnitude on the hanging wall side of the fault, indicative of stronger shaking, is typical of recent observations in strong motion seismology during other similar earthquakes.

\section{OTHER GROUND DAMAGE}

No evidence of liquefaction was observed. This is not unexpected as the recent sediments in the area around the epicentre are coarse alluvial gravels, or in the case of Abbottabad cohesive soils. Neither of these types of materials liquefy during strong earthquake shaking.

\section{BUILDING DAMAGE}

The wide range of building type and construction methods used in the affected area means that a rapid analysis of building damage patterns cannot be undertaken with any degree of reliability. However, in the town of Balakot building damage was strongly asymmetric about a line trending at the same orientation as, and in-line with, the fault rupture zone in the area (Figure 5) and is probably its expression at this site. On the hanging wall side of the lineation almost every building collapsed but on the footwall side of the lineation only about 1 in 10 buildings completely collapsed. Again this is consistent with observations from other reverse or thrust fault earthquakes where shaking was much stronger on the hanging wall side of the fault. 


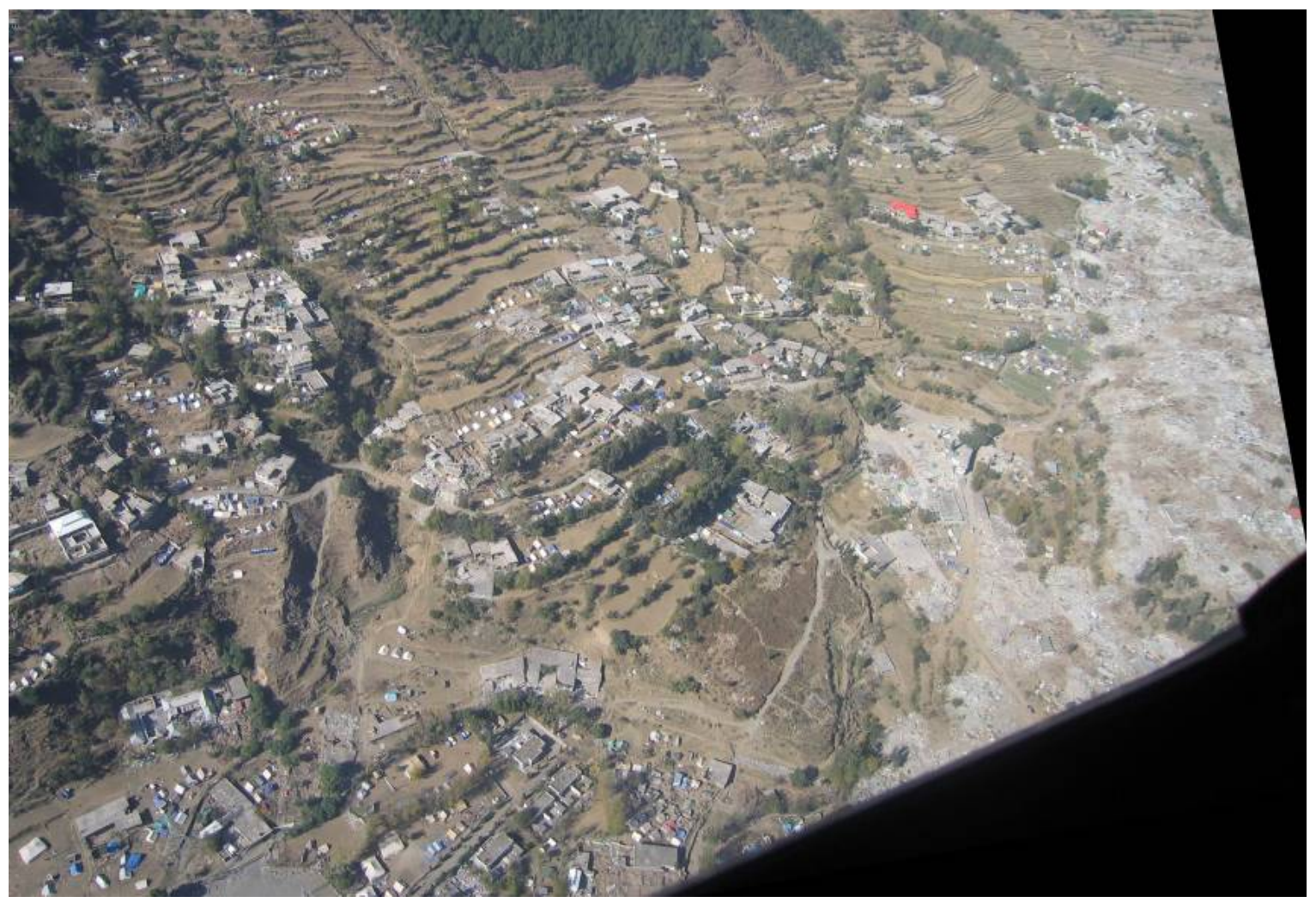

Figure 5. In the town of Balakot building damage is strongly asymmetric and probably delineates the zone of fault rupture. In the area on the right (on the hanging wall) almost every building collapsed, while in the area on the left (on the footwall) 1 in 10 buildings collapsed.

Another area where a noticeable difference in the building damage was observed was on the Abbottabad-Mansehra plateau. At Abbottabad several buildings collapsed or were badly damaged which contrasted with the more limited building damage at Mansehra, although Mansehra was closer to the fault rupture than Abbottabad by a few kilometres. This difference in the building damage between these two towns is probably explained by the contrasting soil foundation conditions. Mansehra is underlain by alluvial gravels (shallow, stiff soil) infilling the basin of the Abbottabad-Mansehra plateau. In Abbottabad the most severely damaged buildings were located on former marshland underlain by cohesive soils (deep, soft soil) with the water-table within 1-2 $\mathrm{m}$ of the ground surface. If the cohesive soils observed in Abbottabad are sufficiently thick this would explain the greater level of building damage in Abbottabad as deep soft soils are capable of amplifying strong ground shaking relative to shallow stiff soils such as probably underlie Mansehra.

\section{CONCLUSIONS}

The magnitude 7.6 earthquake of 8 October 2005 ruptured a fault on or near the western end of the Main Boundary Thrust of the Himalayas in Kashmir and the North West Frontier Province of Pakistan. The Main Boundary Thrust represents the main tectonic boundary between the Eurasian plate in the north which is being thrust over the Indo-Australian plate in the south.

Fault rupture at the ground surface has been reported at three sites over a distance of $\sim 60 \mathrm{~km}$. Dip-slip (reverse) movement of about $1 \mathrm{~m}$ vertical has been documented near
Muzaffarabad (i.e. no lateral offsets have been observed or measured yet). Between the three sites where fault rupture has been recorded or reported the fault rupture zone can be provisionally identified from landslides that coalesce to form a continuous linear feature and strong disparities in building damage in the town of Balakot.

Widespread landsliding was caused by the earthquake with the distribution of landslides highly asymmetric about the ground surface fault rupture. Landslides are also almost continuous along the hanging wall side of the fault zone between Muzaffarabad and Balakot. On the north-eastern (hanging wall) side of the fault extensive landsliding occurred with roads into the Neelum and Kaghan valleys blocked for several weeks after the earthquake. On the south-western (footwall) side of the fault very few landslides were observed and these were generally within 1-2 km of the fault trace.

The landslide and building damage distribution in this earthquake showed a strong hanging wall effect. The highest density of landslides and the sites of the most intense building damage are all adjacent to the fault rupture zone on the hanging wall side of the fault. This indicates near-source ground motions were much stronger on the hanging wall close to the fault than they were on the footwall.

\section{ACKNOWLEDGEMENTS}

The New Zealand Society for Earthquake Engineering, the Earthquake Engineering Research Institute of the United States and the Higher Education Commission of Pakistan are thanked for their financial and logistical support of this 
reconnaissance mission. The authors would especially like to acknowledge the hospitality of the people and government of Pakistan many of who had been badly affected by the earthquake but who were always friendly, helpful and willing to share their experiences.

\section{REFERENCES}

Bird, P., (2003). An updated digital model of plate boundaries; Geochem. Geophys. Geosyst., v. 4 no 3, pp1027-80.
Hancox, G.T., Perrin, N.D., Dellow, G.D., (2002). "Recent studies of historical earthquake-induced landsliding, ground damage, and MM intensity in New Zealand," Bulletin of the New Zealand Society for Earthquake Engineering, Vol. 35, No 2, p59-95.

Officers of the United States Geological Survey, (2005). Earthquake Summary Map XXX: M7.6 Northern Pakistan Earthquake of 8 October 2005; National Earthquake Information Centre, United States Geological Survey. 